\title{
THE JANUS FACE OF RELIGION: ON THE RELIGIOUS FACTOR IN "NEW WARS"
}

\author{
HEINRICH SCHÄFER ${ }^{1}$
}

\section{Summary}

Every religion can be a base for respect and for violence. This is how the Bosnian peace activist Cvijeta Novacovic puts it. The Janus face of religion becomes especially visible when religion and politics mingle closely. This is the case in many of the so called "new wars," as for example in Bosnia, Kashmir, Sri Lanka, and other places.

The present article focuses on how religion works within conflictive environments to mobilize people and to re-structure their identities. First, we will examine the special dynamics of new wars in order to focus the problem. Then, religion will be framed as a specific strategy of identity politics. On this basis we can analyze some ways by which religious logics operate in conflictive settings - for violence or for respect. The Bosnian war will serve as an example in most parts of the article.

\section{Every religion is a base for respect and coexistence and for violence and war. \\ It's up to the people what to do with religion. \\ Cvijeta Novacovic (peace activist, Tuzla)}

The God Janus was said to watch and protect any transition from both sides of the door-panel, inside and outside. Later on, people learned that he had not only two faces but also two personalities.

${ }^{1}$ The author would like to apologize for his fairly "rough" English. Due to an unexpected and extended stay in the hospital, it has not been possible to engage a native speaker for revision. A longer and somewhat different version of this article was produced during the proceedings of a four years international research group on Religion under the conditions of globalization at Chateau de Bossey, the research center of the World Council of Churches. It is a pleasure to thank all my colleagues and the moderator, Julio de Santa Ana, for sharing their expertise and experience. 
In "new wars," religions claim the presence of their gods in every transition, too. If this is to protect or not, and what "personality" these gods develop, will be subject to inquiry in this essay.

In the framework of globalization and the development of different "modernities" (Eisenstadt 2000), religion has during the last decades acquired a role as an important element in a new type of conflicts: regional wars between mobilized cultural (mostly ethnic) identities, so called "new wars."2 In Sri Lanka Buddhist Singhalese and Hindu Tamil people are in conflict, as are Muslims and Hindus in Kashmir, or Orthodox Serbs, Catholic Croats, and Muslim Bosnians in the former Yugoslavia; in Sudan and Nigeria Muslims and Christians, associated with different tribal origins, fight one another. In any of theseand other - conflicts, ethnic, religious, political, social and economic motives mix. Their most important distinction from the classically modern type of war is that ethnic and religious identities play a major role to mobilize the conflict parties. They are important operators in a process of "re-culturing politics" (Senghaas).

In this article we will give special attention to religion in "new wars," and examine its specific role in mobilizing conflict parties and structuring their identities. In order to find a proper focus, we will briefly examine the dynamics of the re-culturing of politics and of waging old and new wars. Then, we will frame religion within the strategies of identity politics and analyze some ways by which religious logics operate. This will allow us to recognize some specific effects of religion in conflictive social environments.

${ }^{2}$ Concepts are still in a flux, as the phenomenon is recent. Because of their characteristics, many scholars speak of a new type of armed conflict as "postmodern," "privatized," "unofficial," "postnational," or simply "new" wars. See, e.g., Ettrich 2001; Kaldor 1999; Knöbl and Schmidt 2000. In this article I follow the approach of Mary Kaldor. Herfried Münkler (2000) doubts that a distinction between old and new wars is helpful. However, even Münkler (2001) states that private actors play a special role in recent conflicts. 


\section{Globalization and the "Re-culturing" of Politics}

"New wars" arise from the transformation of modern political and economic structures under conditions of accelerated globalization during the last decades.

As for the economic structures, Dieter Senghaas (1998:161 ff.) points toward the failure of post colonial developmental nationalism in Third World countries as an important factor for the rise of a militant "re-culturization" of politics. Quite often, those elites who are largely responsible for the failures seek to elude the opposition of frustrated middle classes and the marginalized by enticing ethnic conflicts. Strategies of re-culturization of politics also might affirm particular rights and identities in order to counter influences from outside. In any case, the goal is a new and feasible political project for the actors involved.

Another context of militant ethnic and religious reorientation is the decline of the modern nation state. It gives way to the development of "new visions of collective identity" (Eisenstadt 2000:16) for many kinds of movements, be it religious or secular, multicultural or fundamentalist, communal or ethnic. The nation state's power and legitimacy are being severely eroded. From above, transnational economy and political organizations reduce the state's ability and competence for effective action; from below, the increasing lack of financial resources (e.g., taxes), the increase and privatization of violence, and the very social movements themselves scatter the state's authority; and from the inside, ineffectiveness and corruption dissipate its legitimacy.

Finally, growing social differences between winners and losers from globalization are becoming increasingly visible for everybody. Information technology together with better education among declining social classes all over the world produce a clear sense of an increasing loss of opportunities among many people. As these opportunities are very difficult to regain on the economic or political field, and as there is not always a clearly articulated political consciousness of this situation (Kaldor 1999:117), the field of cultural relations - e.g., ethnic or religious - becomes attractive for the mobilization of people in order 
to achieve political goals. Thus, religion and ethnic belonging can become a resource of political and military power. The violent forms of such mobilization are of interest in this paper.

\section{Old and New Wars}

"New wars" (Kaldor 1999) do away with the solemn, but not very old distinction between war and peace, as for most of their protagonists, "war" means prosperity and peace means decay.

\section{Old Wars}

Modern war has its origin in the nation state. The internal pacification of the state (e.g., the end of feuds) brought about the creation of conscripted and (later) professional armies and potentially hostile relations to other states. Between the 15th and the 19th centuries, war thus developed into a highly governed and controlled activity. The war of Clausewitz is - at least in theory - a rational instrument of political power, and the different conventions of Geneva aimed to regulate and minimize the impact of military activity on civilians. Modern war was organized according to three basic distinctions: public vs. private, domestic vs. external, and civilian vs. military.

As religion in classic modernity belongs to the private sphere, it lost its importance as a reason for war. The state's interest dictates and legitimizes warfare. Religion only serves, besides nationalism, as an additional means to ensure the loyalty of troops and populations.

A first step towards the dissolution of the three basic distinctions created by modern war was the "total war" of the 20th century. Complete societies were subjected to the logic of war: an all encompassing war-economy turned everything into instruments of war; in consequence, everything had to be bombed by the enemy. A second step was guerrilla and counter-insurgency warfare, in both of whichin very different ways! - the civilian population (and thus propaganda) came to be a central factor in military activities. New wars go one step further. 
New Wars

Mary Kaldor analyzes the conflict in Bosnia (1992-1995) as an example of a new kind of war. ${ }^{3}$ This retains some of the characteristics mentioned above. Yugoslavia was transformed from communist to capitalist modernity with less precipitation than, e.g., the Soviet Union, but with considerable friction. From above, the crisis of the Yugoslavian state created a lack of legitimacy for the ruling political elites. From below, economic decline and separationist politics fueled a climate of insecurity. Given an increasing scarcity of political resources, the elites changed from communist to nationalist discourse, articulating nationalism through ethnic and religious identities.

The ante bellum society in Bosnia, however, did not by itself evidence relations of "centuries old hatred," as some politicians put it, nor was it a multicultural wonderland. While certain differences between more liberal urban and more traditional rural areas existed, people "were conscious about national and religious differences in their closer environment, without taking them as potential reasons for conflict" (Calic 1998:338). Nevertheless, due to historical reasons, religion (not language, Serbo-Croatian) was the most important distinctive element in ethnic terms, even if religious practice had lost much of its significance during communist rule. ${ }^{4}$ Bosnian Muslims are ethnic Serbs who converted during the Ottoman rule (1389 to mid-17th century), and who held, since then, the economically strongest positions in Bosnian society, with a slight urban emphasis. Orthodox Serbs, and a Catholic Croatian minority, traditionally represent weaker social positions and a slight rural emphasis. Since the Ottoman Empire, the "millet system" (different religions in one administrative unit) had created a space for the coexistence of these groups in Bosnia. This kind of "good neighborhood" (komsiluk) has been called an "institutionalized

${ }^{3}$ On the conflict in Bosnia, see especially Kaldor 1999, and Sells 1996, as well as Bremer 2003, Calic 1996, Calic 1998, Dartel 2000, Melcic 1999, Powers 1996, and Shenk 1993.

${ }^{4}$ In 1990, 61\% of young Bosnian Muslims had never visited a mosque, $70 \%$ of Serbian and 35\% of Croatian youths had never looked into a Church (Calic 1998:343). 
communitarianism" (Xavier Bougarel), even if differences between urban and rural settings have to be taken into account. Intercultural ties, such as intermarriage and an encompassing secular culture in the cities, were fostered even more by communist secularism under Tito. Correspondingly, six months before the elections of $1990,74 \%$ of the voters welcomed a possible proscription of nationalist parties in order to preserve good neighborhood relations. But it turned out differently.

Political mobilization took place along the lines of religiously defined ethnic-nationalist parties of Croat, Serb and Muslim orientation. ${ }^{5}$ Traditional forms of power-sharing deteriorated quickly. The government coalition and the parliament fell apart in 1991. The nationalist parties began to organize and even arm "their" peoples according to ethnic and religious criteria, and "autonomous areas" were being defined (Calic 1998:349). In consequence people had few options other than to rally around their own ethnic-religious tradition. But these traditions were already caught up in a dynamic of political polarization, heated buy religious institutions (Kaldor 1999:67 ff.) A new war broke out, initiated by snipers opening fire on the peace movement in Sarajevo, thus indicating its main goal: the elimination of a "secular, multicultural, pluralistic society" (Kaldor 1999:72). ${ }^{6}$

The most important characteristic of the war in Bosnia, according to Mary Kaldor, is that it was waged by different power groups (not by the state) against civilians. This, first, turns the concept of modern war upside down, according to which regular troops fight against each other. Second, it also changes the concept of guerrilla and counterinsurgency warfare, inasmuch as now the state is no longer the most

${ }^{5}$ Only the ex-communists and a reformist alliance were explicitly multi-ethnic (Calic 1998:348).

${ }^{6}$ One might be tempted to see here a cultural fault-line-conflict according to the Huntington model (Huntington 1993, 1996). But it turns out to be the other way around. Political and economic interests mobilized ethnic and religious traditions in a situation of crisis. The basic problem here is not culture but politics. Thus, the approach to the conflict as an outburst of centuries-old hatred, instead of serving as an analytical tool, simply reproduces the discourse of ethnical and religious particularists. 
important military actor. Third, the raison d'état is no longer the ideological reference point, but ethnic origin, religious orientation and money (resources etc.) take its place.

Instead of the state, "private" actors become increasingly important: paramilitary groups under criminal leaders partly cooperate with the state and partly do their own business with warfare and collateral damages. Foreign mercenaries (Mujahedin or private military firms) engage with different parties for the sake of money, recognition by political elites, or even adventure. Local militias in turn search to protect villages from these groups. Finally, regular troops of interested states or state-like constructions engage in the fighting, as well as international, regular military (e.g., UN-troops, NATO, the United States). In Bosnia - as in many other places, like Rwanda or Somalia regular troops were not in a position to protect civilians, even if they were willing to do so. The most important military actors were irregular forces that acted flexibly, widely dispersed throughout the country but at the same time in close contact by means of state of the art communications technology. Their main target was the civilian population. In order to gain political control over the population, terror against civilians (threats, shootings, violations, expulsions) was systematically employed to achieve religious/ethnic "cleansing" of territories and divisions between them. In an economic situation that did not allow for much more than to survive on humanitarian aid, to flee or to become criminal, the members of the paramilitary groups decided for the latter. While the regular troops and mercenaries were mostly paid from the outside (by governments or diaspora communities), the irregular troops financed their subsistence and warfare to a large extent by means of illegal "war-taxes" exacted on whatever possible, by extortion, robbing, pillage, smuggling (weapons, drugs, diamonds, etc.), black market business, etc. For this reason, even the economic logic of war is turned upside down: whereas the activites of a regular soldier in modern wars is not a lucrative business, members of paramilitary forces - specially the higher ranking — are able to turn war and common insecurity into a source of income. Consequently, their goal is not to reestablish civil institutions and public security, but quite the oppo- 
site: to maintain as long as possible a state of common insecurity and the rule of the stronger. As war is business and the civilians are the main target, it is no wonder that irregular forces do not establish clear fronts nor seek battle with the enemy forces. On the contrary, they avoid battle and even bargain with the enemy about economic benefits against military control or action.

Thus, it is not even predictable with a high range of probability whether, e.g., a Serbian informal unit would act or not against the Croat population of a certain village. It might choose not to do so, if a deal with a unit of Croat irregulars has been negotiated. But one thing is always almost certain to take place: any group of irregular forces represses, terrorizes, or exterminates moderate civilians. Ethnic "cleansings" target, of course, members of other ethnic-religious groups. But, as Mary Kaldor (1999:91f.) points out, a very important other target group are those who seek to bridge the gaps, moderate conflicts, and help their neighbors - whatever ethnic origin they are: Serbs who hide or defend their Muslim neighbors, Jews who help the Muslims flee, and many other courageous individuals.

Summing up, it may be said that a "new war" does away with the most important characteristics of the modern type of war. Especially clear is that the main military target is the civilian population, that the most important fighters are irregular paramilitary groups (sometimes in conjunction with regular forces), and that the aim of their actions is not so much control of territories by military presence as political control over civilians by terror. Irregular fighters and the politicians behind them turn religion into a public identity marker to flag out civilians as either targets or supply base.

\section{Identity Politics}

Many of the "new war"-type conflicts follow the logic of an "ethnicization" of social relationships (Eder et al. 2002; Eder 1998). In many cases, ${ }^{7}$ this is equivalent to "religicization." According to this approach, it is erroneous to think that ethnic or religious belonging itself

\footnotetext{
${ }^{7}$ E.g., Bosnia, Sri Lanka, Kashmir, Palestine, and Northern Ireland.
} 
is the reason for conflicts. The latter opinion corresponds rather to the nationalist theory - going back to Herder - that nations themselves are rooted in ethnicity. Instead, what happens is that new war protagonists overstate ethnic and religious traditions in search for political power. Much like religious fundamentalism, this process is anchored in traditions of everyday life, selects certain symbols, stresses them as emblematic for certain "ethnic" or "religious" identities, and combines them with political programs over against other groups. Such identities are at the same time traditional and constructed. They correspond to feelings of belonging and emphasize artificial contradictions. They are traditional in terms of the central contents of their discourse: they use old and well known symbols, refer to collective memory, and operate according to habitual practices of certain populations. They are constructed in terms of the boundaries that they draw by overstating certain contents over against alleged enemies; they use symbols, etc. to mark differences and contradictions, and to produce self-recognition within a group through the exclusion of others. Emblematic labels serve for both aspects of the process.

In this way, traditional religious and ethnic belonging can be transformed into a resource for political power. In situations in which economic or political resources are too scarce to be used for reaching political goals or control economic goods, elites can construct conflictive sceneries and mobilize people on ethnic and/or religious grounds. As stated at the beginning of this article, such a situation can be the breakdown of a nation state, a developmental crisis, or the collective confrontation with an extremely strong external pressure. As the once overarching distinction between left and right is becoming more and more meaningless, and as even political opposition to globalization turns more and more global itself, social contradictions between winners and losers of globalization can no longer be clearly articulated in political terms. Consequently, the void of political self-definition under such conditions is ready to be filled with ethnic and religious identity discourse, and socio-economic problems are transformed into symbolic violence. 
Collective identity, religious or ethnic, is a resource both for those with economic and/or political power and for those without it (Eder 1998:30). But identity politics run the danger of an uncontrollable development since they bargain with a good that can not be bargained with: identity. The scenario of new wars shows an important characteristic. It is neither true nor false that new wars lack rationality. For the ethnic-nationalist, religious and (para-)military elites conducting it, a new war is primarily a purposive rational enterprise to further their political and economic benefits ${ }^{8}$ — even if they might personally identify with their ethnic or religious backgrounds. For the mobilized marginal population, however, ethnic and religious identity is much more than a political calculus. Their religious and/or ethnic identity represents for them truth, life and dignity. Thus, some hardly calculable factors enter into the political game.

Goldstein and Rayner (1994:367 f.) state the differences between conflicts related to identity and to interest. According to them, conflicts about interests have a clear focus and can be addressed quite easily, because they involve "third things" like material goods or political positions. The strategies point towards material betterment, which people value less than life itself. Negotiation is possible. Interest oriented conflicts also correspond to the highly developed rational choice framework of modern politics. Identity conflicts, on the other hand, are very hard to address politically. Negotiation is much more difficult, especially under the presuppositions of a rational choice framework. This is because identity conflicts resist clarity of goals and reasons, and tend to mystification. Moreover, they involve the intricate logics of self-esteem, dignity and recognition, and the sense of belonging of the actors. The actors orient their strategies (from negotiation to suicide bombing) by dispositions that are anchored, beyond the limits even of the individual itself, in religion and community, which means that individual life is not of primary importance. This strategy of collective identity affirmation is precisely what answers the demand of

\footnotetext{
${ }^{8}$ Kaldor 1999:160. This is the case even in the sense that normative regulations or traditional ritualization of warfare is being ignored for the sake of more effectiveness.
} 
individuals when they are uprooted and lack cognitive and emotional dispositions to get along with a new and violent situation.

In such circumstances, (former) governmental, political or intellectual elites, traditional leaders, religious personalities and skillful criminals can serve their own material interests by mobilizing people through ethnic and religious discourse. The higher the insecurity they themselves produce, the more attractive becomes what they offer, and the fewer alternatives remain that may be built on everyday cooperation or religious syncretism. The deeper people can be engaged in collective violence, moreover, the stronger is the cohesion that may be produced by the bonds of guilt and hatred. Such an environment fosters a typical combination of factors supporting religious identity politics in the context of new wars: the main actors are increasingly non-governmental groups, movements and organizations; the main resource for mobilization is discourse, and for implementation symbolic and physical violence; and the main contents of discourse is a mix of religious and ethnic elements. But the conducting logic is double edged: a purposive, materially oriented rationality among the elites, and religious-ethnic identity affirmation among their followers.

\section{Religion}

Religion is an important condensational point of mobilized identities, especially in non-European modernities and in traditional societies. Religious identities facilitate both particularist and cosmopoli$\tan ^{9}$ strategies in contexts of violence. Particularists (or fundamentalists) seek to impose their particular criteria universally or, at least, upon everybody within certain territories. Cosmopolitans foster values of universal humanity in any particular case. The former exclude others by own standards. The latter join with others, according to standards of mutual human acceptance.

\footnotetext{
${ }^{9}$ The distinction between cosmopolitan and fundamentalist (particularist) orientations refers to Giddens 1994 . Kaldor (1999) elaborates with it very interesting alternatives for international intervention into new war-type conflicts.
} 
Religious Identities

It can be affirmed that, on the macro level, the boundaries between ethnic units are largely congruent with the lines of religious differences. This is due to the fact that, especially in traditional societies, religion makes up very much of the ordinary people's social (and ethnic) identity. Only modernity, rapid migrational movements and multicultural societies of today (like Canada or Malaysia) seem to change the picture. But still, multicultural and multireligious formations existed much earlier, too (e.g., under the Ottomans in Bosnia, or the Muslim rule in Spain). However, even in a multicultural setting, religion often plays an important role as a cultural identity marker for the ethnic groups implied. Even more: as the example of the USA shows, civil religion can overwhelm different religious identities as an ideology of national unity, but implicitly confirm the dominance of one ethnic group over the whole multicultural setting. ${ }^{10}$

On the micro level of collective identities, religion can be understood as a specific condensation of culture. We can think about a collective cultural identity as a broad network of habitual dispositions to perceive, to judge and to act, common to all actors of a certain culture and, at the same time, comprising some specific differences according to individuals, groups, social classes, etc. (Schäfer 2003). Religion can be modeled as a region on this network, where the fabric of signification has "the color of" religion and traditionally is very densely woven. Even in European secularized societies - like Yugoslavia where religion may no longer be very central to the collective cognitive network, it still serves as a common reference. However, in the period preceding a new war, collective religious dispositions often become very important operators for mobilization.

Symbolic Violence

In a context of decaying nation states and a growing significance of non-governmental actors, public discourse becomes increasingly

${ }^{10}$ Possibly, Indonesian panjasila works much the same way on the basis of Islam. 
important in general and, more specifically, for the exercise of power (Eder 2000:29, $201 \mathrm{ff}$.). Especially in new wars, social movements and organizations (like paramilitary groups) confront one another. Ethnic and religious identity-mobilization operates with symbolic boundaries as follows: as an identity is being constructed, some people are included in it and, by the very same act, others are excluded. This is still quite normal and does not lead to problems in everyday life, as long as communication is flowing and expectations are basically positive. But if resources are scarce and interests polarize, the identities reaffirm themselves in contrast to one another, and the gaps between them widen. Actors perceive any competing identity as a threat - not only to certain limited interests, but to their own identity: to everything they are.

In these clashes of mobilized identities symbolic violence ${ }^{11}$ gains an important role in religious discourse. First of all, it means not to recognize the identity of the others as legitimate. Thus, it implies negative ascription (labeling), such as, e.g., racial discrimination, downgrading and ignoring; obstruction of the counterpart's means to express her- or himself; use of unjust, false, manipulative, etc. affirmations and discursive techniques against the other; and blocking the communication channels to and from the other. Strong actors normally opt for racism, weak actors for the "strategy of exclusive selfrecognition" (Eder 2000:203).

Religion plays an important role in these processes, especially in combination with ethnic identity. Religious socialization - through life-cycle rites, schools, family traditions, etc. — combines closely with the formation of cultural habitus. In case of ethnic mobilization, therefore, religion for many people represents an anchor-point for ethnic self-recognition. Habitual dispositions to combine religious

\footnotetext{
"We understand the term "symbolic" according to Pierre Bourdieu not so much in the sense of representation of something, but in the sense of recognition. E.g., one can understand a shaman as a representation of the divine; but this depends upon the fact that one recognizes him as such. For symbolic representation to be realized, the social relationship of recognition between an actor and a "symbol" is required.
} 
and cultural practices, learned since primary socialization, can become highly salient in situations of conflict and the construction of (counter-)identities. Deep-rooted religious sentiments of belonging can thus be used as widely recognized emblematic markers for political identification. It helps even more that religion provides many ancient and long standing means for dramatizing and representing identities, like processions, shrines, life-cycle rites, everyday rites, meaningful buildings, etc. In many cases these practices and objects are combined with places or territories. But with modern mobility and growing diaspora, religious symbols become transnational as well - even though they still might be linked to significant places like Mecca or Rome. In situations of crisis, these anchor points provide a resource of emotional security for the individuals and, at the same time, link these people to strategies of politically interested identity mobilization.

In this context, religion offers a double usage to those who manipulate it. Generally, it is open to being combined with arguments of reason and common sense. Thus, it can be linked to secular political discourse, furthering even secularist goals. ${ }^{12}$ On the other hand, religion does not have to be reasonable in a "worldly" sense. Consequently, religion is a strong means to overcome instrumental rationality (such as presupposed in rational choice-models of human action). The example of Palestinian suicide bombers shows that the sense of belonging to a community and the concrete expectation for Paradise introduces another kind of rationality, the criteria of which reside far beyond individual benefits. ${ }^{13}$ And finally, religion also comprises a certain tendency to make the actors believe that their positions are absolute (and not relative to others). This leads to fundamentalist mobilization. ${ }^{14} \mathrm{Re}-$ ligion, as well as ethnic reason, constructs for people a virtual linkage

\footnotetext{
${ }^{12}$ As it does the classical protestant argument for the separation of Church and State.

${ }^{13}$ See, on interviews with suicide bombers, Hassan 2001.

${ }^{14}$ On the practical logic of fundamentalisms, see Schäfer 2005.
} 
to common primordial roots. This fact fosters the effectiveness of religious identity construction and the implementation of religious symbolic violence in the scenarios of new wars.

\section{Disruptive Mobilization}

For the main protagonists in new wars, religion serves primarily as a resource to mobilize people behind (ethnically framed) political interests. As an example, we take a closer look at the Bosnian experience. ${ }^{15}$

As a heritage from the Ottoman millet-system and Tito's Yugoslavia, the urban culture in Bosnia was quite secular in pre-war society. The spoken language was not an identity marker since SerboCroatian was common to everybody. Religious differences were the only important markers of distinctiveness between ethic groups even though much of the Muslim population ethnically is Serbian as well, since their ancestors (Serbian petty aristocracy) had converted to Islam under Ottoman rule. The Serbian Orthodox Church (existing since the 10th century in the region) became under Ottoman rule an important agent of self-affirmation for the regional non-Muslim population. But it was only in the nineteenth century that religion and national identification became more closely related (Calic 1998:339). Nonetheless, religious differences lost their importance during the Communist era by an increasing secularization and by religious intermarriage, especially in the cities. ${ }^{16}$

The old concept of "good neighborhood" (komsiluk) in daily life had its religious correspondence in syncretic practices. " ${ }^{17}$ "Even today the same amulets are worn by both, Christians and Muslims. The Virgin Mary is as venerated among Muslims as among Christians

\footnotetext{
${ }^{15}$ For the religious aspects of the Bosnian war referred to in the following, see Sells 1998, as well as Bremer 2003, Calic 1998, Powers 1996, Shenk 1993, and Tschuy 1997.

${ }^{16}$ Less than half of Bosnian Muslims, and Croats and only $25 \%$ of Bosnian Serbs, in 1991, saw ethno-religious belonging as a criterion for marriage (Calic 1998:345).

${ }^{17}$ Very similar practices underlie the kashmiriyat in Kashmir, presently being destroyed by Muslim-Hindu polarization.
} 
... Christians sometimes invite Muslim dervishes to dance and read passages from the Qur'an at their festivals" (Tschuy 1997:106).

Nevertheless, religion was still a strong possible resource for distinction. The conflictive history of the region had contributed to the development and spread of ethnical-religious myths like the one of the Christ-like Serbian king Lazar, a myth that is deeply anchored in the collective memory and can be linked to remembrances of particular events like atrocities during World War II. Religious myths can gain a life for themselves and serve as rationale for "counter"-action later on, as it has been the case with the alleged destruction of Serbian monasteries and the genocide against Serbs by Kosovar Albanians in 1986 that served to legitimize Serbian inroads on Muslims. ${ }^{18}$

Because they are rooted in everyday socialization - mother's tales and family chats over lunch - especially older socio-religious myths have a strong potential for mobilization. Myths are of direct use for political interest groups, Church leaders and elites in their strategies of ethnic identity mobilization by discourse. A strong example for the political construction of an ethnic-religious myth can be found in the activities surrounding the 600th anniversary of the battle at Kosovo Polje in 1989. According to Sells $(1998,1999)$, this celebration served as the culmination point of many propaganda activities with the same focus: to construct a belligerent ethnic-religious Serbian identity. One of these activities was misinformation about the alleged destruction of monasteries. Others were the ritual exhumation of bones of Serbs killed by the Nazis during WW II, and nationalist propaganda depicting Muslim Serbs, Croats and Albanians as genocidal. During the commemoration of the battle at Kosovo Polje, in 1989, on location, the symbols were joined together by Slobodan Milosevic and leaders of the Serbian Orthodox Church. The medieval prince Lazar, killed in the battle by the Turks, was depicted as a Christ-like figure so that the

\footnotetext{
${ }^{18}$ According to Sells (1999) the allegations were proved false by independent research, which only showed some isolated cases of vandalism, some graffiti and cut trees on Church property, as well as one rape in one year: hate crimes, but not genocide.
} 
defeat could be called the "Serbian Golgotha." The historical Serbian heartland of Kosovo thus appeared as the "Serbian Jerusalem." In this scenery, the murders committed by the Nazis during WW II and the alleged attacks against Orthodox monasteries became religiously and militarily charged symbols.

This symbolic operation reaches still deeper, if seen in the context of "Christoslavism." The opinion that Slavs are Christian by the very essence of their being Slavs uses religion to absolutize an ethnic identity. It replaces ethnic belonging with religious orientation and constructs an ethnic nationalist identity by religious means. This operation of practical logic works the other way around, too: all those Serbs who (historically) have converted to Islam are no longer Serbs but "Turks." And as such they are to be made fully responsible for the death of king Lazar on the "Serbian Golgotha."

These operations of combined political, ethnical and religious discourse produced (or invented) a new combined religious-ethnic identity: the strictly Orthodox Serbian one. The most important boundary is drawn against ethnic Serbs with a Muslim creed. This means that these people are the most dangerous ones for the fresh identity - precisely because of similarities and not because of differences. As a partly invented identity, the Orthodox-Serbian one had to focus very much on preserving itself from "alien contamination" (Goldstein and Rayner 1994:372).

Such preservation can be done very effectively by ethnic-religious "cleansing" through military forces. And this was precisely what the combination of symbols in the Kosovo-Polje commemoration festival pointed to. The effect of this symbolic conglomerate on (potentially mobilized) Serbian Orthodox people was quite obvious: "all Muslims have the blood of king Lazar and the Serbian people on their hands, since 1389 , in order to occupy our heartlands." So "cleansings" may be seen as a logical reaction.

Finally, religion, in this use, not just legitimizes political violence. It is a driving force of violence, and it gives direction to it. In the scenery of a new ethnic war, according to Mary Kaldor (1999:159), it is important to render certain regions uninhabitable for certain 
people. In this sense, genocidal action is incomplete, if it leaves the symbols of religious identification intact. People of a region can be driven out of it, but they long to come back as long as their memory links them to it with pleasant bonds, such as, for instance, a former home and religious site. Therefore, systematical rape and physical atrocities may be effective weapons to destroy the desire of people to reclaim their places. Another important weapon is the systematic destruction of religious sites, thus uprooting deep-seated identifications. It is no wonder that (para-)military forces composed by Bosnian Serbs systematically destroyed non-Orthodox sacral sites, removed the rubble and turned the locations into something else, for instance parking lots, and others did similar things to Serbs. Religious symbolic violence is an important element to extinguish the sense of belonging, to uproot people and to make a region psychologically uninhabitable to them.

To damage other people's identities so severely that they can no longer inhabit their native places is one of the most extreme goals of particularist strategies. But religious and military polarization cannot tear everything apart.

\section{Cosmopolitan Practice}

Religion also has the capability to strengthen cosmopolitan attitudes, because it is not bound to ascribe absoluteness to human projects. It is also able to relativize any human action in contrast to the sacred.

This capacity is partly due to the close connection that traditional folk religion maintains with the flexible practical logic of everyday life. Traditional syncretism in the context of good neighborhood relations provides strong roots for both faith and human solidarity. Even under the extreme stress of ethnic-religious "cleansing" in Bosnia, there were religious people willing to risk their lives helping persecuted believers from other religions. This kind of attitude - though strongly traditional in average actors, especially peasants - is closely related to the cosmopolitan worldview of the peace movement, of NGOs, of ecumenical organizations and others who seek to mediate and 
reconstruct civil society under the conditions of new wars. It expresses a fundamental logic of social peacekeeping.

The town of Tuzla offers a special example of a cosmopolitan attitude. According to Cvijeta Novacovic, ${ }^{19}$ the majority of the population of Tuzla, from the beginning of the war, opted against nationalist alternatives and tried to keep a "normal life" in town. A key issue was the first shelling of the town by paramilitary forces, the start of the war for Tuzla. Nobody was prepared, and the grenades hit a feast celebrated by the town's youths. As their answer, the people decided to conduct a joint funeral service with Orthodox, Muslim and Catholic ministers. The funeral was held during the night, and, according to Novacovic, the service remained an important symbol for a cosmopolitan attitude of Tuzlan people and for their resistance to ethno-religious war. Novacovic and many others became activists organizing cooperation for peace.

In contexts like the Bosnian war, during open hostilities, cosmopolitan actors naturally do not have the best conditions to mobilize people for peace. Civil and Human Rights Groups, NGOs, humanist intellectuals and ordinary individuals are normally weak actors in heavily polarized and violent environments. Cosmopolitan actors immediately contradict, by their very action, the logic of new war itself. Someone who opts for reconstructing legitimate and legal institutions, to defend Human Rights, to maintain or revive interreligious tolerance, and to foster multicultural, pluralistic and democratic societies is more dangerous to any paramilitary group than any person aligned with the enemy. As mentioned above, implicit and explicit cosmopolitans are preferred targets of irregular combatants. But cosmopolitan groups can also be partners of peacekeeping international forces, a partnership that improves their position at least in post-war scenarios.

Religion, in any case, has a totally different role among this kind of actors. It is anchored in everyday syncretism, as exemplified by Muslim virgin adoration or dervishes visiting Christian homes. Everyday

\footnotetext{
${ }^{19}$ A peace activist from Tuzla in a report to the interreligious "Visser t'Hooft Consultation on Religion, Power and Violence," June 8-13, 2004, Chateau de Bossey.
} 
religion is not primarily concerned with boundary construction, but with problem solving - the classical operation of what Max Weber called the "sorcerer." Problem solving demands an open eye for possibilities for cooperation with others, regardless whether they are of the same religious confession or not. Traditional, or explicitly ecumenical actors do not stop believing in their own particular, distinctive God. But their interest in problem solving makes them search bonds to other people rather than boundaries. There are two major ways to construct a religious bond to a neighbor of a different confession. First, actors can construct the bond by reference to a transcendent God. This kind of religious logic departs from a basic distinction between "needy human beings" and "the same almighty God." One acts as if there were just one God for all humans, without explicitly stressing differences. Moreover, one may keep silence about different religious practices, or one may emphasize commonalities. In any case, the most important goal in conflictive environments will be to achieve a live saving solidarity "in the name of God." Second, actors may construct the bond with others by reference to human transcendence. This kind of logic departs from a distinction between "needy human beings" and "the mystery of many gods." It is tolerated that others might have a different God (or erroneous beliefs), but they are nevertheless seen as fellow human beings. Here, solidarity is testimony of one's own faith in the name of a "common humanity." Both ways work. However, this practical religious relativism does not eliminate firm personal beliefs that are anchored in traditional or ecumenical value orientations and deeply stored in the habitus. The logics of human solidarity for reasons of faith can be rooted so deeply that people risk or give their lives for persecuted neighbors, whatever religion they may confess. Many examples from Bosnia and other conflictive regions give evidence of this.

Traditional everyday religion is a fragile network that is easily torn apart if severe shortage of economic or political resources combines with heavy ethno-religious propaganda. But it links up in a very "nat- 
ural" way with the cosmopolitan practice of ecumenical organizations, Human Rights associations, NGOs, and similar actors. ${ }^{20}$

\section{Some Concluding Remarks}

What is the specific role of religion in a new war-scenario?

First of all, reference may be made to a general characteristic of religion. Religion makes people refer to a reality which is "not of this world" (Schäfer 2004:332ff.). This reference is a key element in the construction of religious identity. It is in itself Janus faced, ambivalent, inasmuch as it bears two polar possibilities of development: fundamentalism and practical relativism. In the case of fundamentalism (Schäfer 2005), a group identifies its own position (religious, ethnic, social, political, etc.) with the meta-social and absolute entity, with the divine itself. Thus, fundamentalisms of different shapes all promote their particular and relative beliefs as having absolute and universal validity. This is the material that ethno-religious militancy is made of. On the other hand, the reference to an absolute and transcendent entity can induce believers to respect limits to human knowledge and pretense. Thus, an implicit and practical relativism is generated. As a consequence, the actors will respect other human beings simply for their being human. Both possibilities can be observed in the same conflictive context. We described one of them as a particularist attitude and the other as a cosmopolitan one. The former corresponds more to political and military power-broking, the latter to lifesaving and peacemaking social strategies and the practice of problem-solving everydayreligion.

Second, religion tends to enter into a close relationship with ethnic identity. It serves to handle social conflicts by symbolic means. In traditional everyday religion the link between primordial religious and ethnic roots is being tacitly presupposed. Usually, in a traditional village nobody questions that the gods of the ancestors are the gods of the present, too - unless the traditional structure of the village suffers

\footnotetext{
${ }^{20}$ On initiatives of religious leaders, see Dartel 2000.
} 
deterioration by some economic or political change (Annis 1987). In particularist religious mobilization with ethno-nationalist interests, on the other hand, the identification of religious and ethnic origins is being politically constructed. The Serbian Orthodox identity, based on king Lazar, may serve as an example. The two forms of religious identities obviously do not represent the same practical logic and, therefore, do not trigger the same action. But they are similar in terms of the symbols they employ. This means that they are being perceived by the public as more or less the same religion. Thus, traditional religious practice can easily be coopted and manipulated by particularist practice.

Third, religion in general refers to an absolute, meta-social entity as well as to primordial (ethnic) roots of a certain group of people. It provides two key reference points for the personal identity of group members. This is very significant, if people are highly religious - be it because of external pressure or traditional habitus. These individuals construct their identities as dependent, at the same time, upon the absolute and upon the group's deep-rooted religious origins. The group as such turns out to guarantee the existence of the divine for its members, and the divine in turn legitimizes the existence and the goals of the group. Due to this kind of identity construction, the individual tends to value his or her own life below the divine and/or the community. This is basically the case in many non-western and nonindividualist cultures, in religious orders or in some fundamentalist circles. Regarding the practical consequences of this basic attitude we only want to mention two extremes: if the individual identifies its community of reference as "humanity," the personal identity will turn out to be basically cosmopolitan, and it may be that the individual sacrifices his or her own life for other people in danger. If the community of reference is simply a particularist group, the personal identity will be basically fundamentalist, and the individual might sacrifice his or her life in a suicide bombing against those who are perceived as attacking the group.

Religion is deeply ambivalent. It is both, a base for "respect and coexistence and for violence and war" (Novacovic). Ethno-religious 
violence in new wars polarizes people and makes this Janus face of religion visible.

Universität Hannover

HEINRICH SCHÄFER

Seminar für Religionswissenschaft

Im Moore 21

D-30167 Hannover

Germany

HeinrichSchaefer@gmx.net

www.rewi.uni-hannover.de/schaefer.htm

\section{REFERENCES}

Annis, Sheldon

1987 God and Production in a Guatemalan Town. Austin: University of Texas Press.

Bremer, Thomas

2003 Kleine Geschichte der Religionen in Jugoslawien. Freiburg: Herder.

Calic, Marie-Janine

1996 Krieg und Frieden in Bosnien-Herzegowina. Frankfurt: Suhrkamp.

1998 "Religion und Nationalismus im jugoslawischen Krieg." In Heiner Bielefeldt (ed.), Politisierte Religion, Frankfurt: Suhrkamp, 337-59.

Dartel, Geert van

2000 "Interreligious Dialogue in the Balkans." Studies in Interreligious Dialogue $10(2): 160-65$.

Eder, Klaus

1998 "Protest und symbolische Gewalt: Zur Logik der Mobilisierung kollektiver Identitäten." Forschungsjournal Neue Soziale Bewegungen 11(4):29-40.

2000 Kulturelle Identität zwischen Tradition und Utopie: Soziale Bewegungen als Ort gesellschaftlicher Lernprozesse. Frankfurt: Campus.

Eder, Klaus et al.

2002 Collective Identities in Action: A Sociological Approach to Ethnicity. Aldershot: Ashgate.

Eisenstadt, Shmuel

2000 "Multiple modernities." Daedalus 129:1-30.

Ettrich, Frank

2001 "'Neue Kriege' und die Soziologie des Krieges." Berliner Journal für Soziologie 11(3):391-404. 
Giddens, Anthony

1994 Beyond Left and Right: The Future of Radical Politics. Cambridge: Polity Press.

Goldstein, Jonah, and Jeremy Rayner

1994 "The politics of Identity in Late Modern Society." Theory and Society 23:367-84.

Hassan, Nasra

2001 "An Arsenal of believers." The New Yorker, November 19, 36-41.

Huntington, Samuel

1993 "The clash of civilizations?" Foreign Affairs 72(3):22-49.

1996 The clash of civilizations. New York: Simon and Schuster.

Kaldor, Mary

1999 New and Old Wars: Organized Violence in a Global Era. Stanford: Stanford University Press. (German (ed.), Neue und alte Kriege: Organisierte Gewalt im Zeitalter der Globalisierung. Frankfurt: Suhrkamp 2000.)

Knöbl, Wolfgang, and Gunnar Schmidt

2000 (ed.) Die Gegenwart des Krieges: Staatliche Gewalt in der Moderne. Frankfurt: Fischer.

Melcic, Dunja

1999 (ed.) Der Jugoslawien-Krieg. Handbuch zu Vorgeschichte, Verlauf und Konsequenzen. Wiesbaden: Westdeutscher Verlag.

Münkler, Herfried

2000 "Die Kriege der Zukunft und die Zukunft der Staaten: Von der prekären Verständigung politischer Akteure und der Rolle der Gewalt." In Knöbl and Schmidt 2000:52-71.

2001 "Die privatisierten Kriege des 21. Jahrhunderts." Merkur 55:222-34.

Powers, Gerard

1996 "Religion, conflict and prospects of reconciliation in Bosnia, Croatia and Yugoslavia." Journal of International Affairs 50(Summer):220-52.

Schäfer, Heinrich

2003 "Zur Theorie von kollektiver Identität und Habitus am Beispiel sozialer Bewegungen. Eine Theoriestudie auf der Grundlage einer interkulturellen Untersuchung zweier religiöser Bewegungen." Berlin: Humboldt Universität (microfiche), 497. (Doctoral dissertation in sociology).

2004 Praxis-Theologie - Religion: Grundlinien einer Theologie- und Religionstheorie im Anschluss an Pierre Bourdieu. Frankfurt: Lembeck.

2005 (in preparation) "Religious Fundamentalisms and Reflexive Modernity." In Julio de Santa Ana (ed.), Modernities, Religions and Ecumenism (Final 
report of the Bossey/World Council of Churches research group on The current situation of religious life and its challenges to the Ecumenical Movement).

Sells, Michael

1998 The Bridge Betrayed: Religion and Genocide in Bosnia. Berkeley: University of California Press.

1999 "How Serbs used Monasteries to Ethnic Hatred." http://www.alb-net. $\mathrm{com} / \mathrm{kcc} / 061499 \mathrm{e} . \mathrm{htm} \# 15$ (15 June 1999).

Senghaas, Dieter

1998 Zivilisierung wider Willen: Der Konflikt der Kulturen mit sich selbst. Frankfurt: Suhrkamp.

Shenk, Gerald

1993 (ed.) God with us? The role of religion in conflicts in the former Yugoslavia. Uppsala: Life and Peace Institute.

Tschuy, Theo

1997 Ethmic Conflict and Religion. Geneva: World Council of Churches. 